\title{
Confiscated Manuscripts and Books: What Happened to the Personal Library and Archive of Hugo Grotius Following His Arrest on Charges of High Treason in August 1618?
}

\author{
Martine Julia van Ittersum
}

Mindful of his own mortality, Hugo Grotius (1583-1645) wrote to his younger brother in March 1643 that he was preparing a set of manuscripts - "for the writing of which God created me in the first place" - for publication by his heirs. Sixty years old at the time, the Dutch jurist and polymath already had a distinguished publishing record. His intellectual and literary interests ran the gamut from poetry and philology to law, politics, history and theology. The authoritative bibliography of his printed works, compiled by Jacob ter Meulen and P.J.J. Diermanse during the Second World War, lists over 1,330 different editions including reprints in later centuries. The corpus of Grotius' writings has expanded even further in recent times. Early treatises like De Republica Emendanda (1600), Meletius (1611), and Tractatus de iure magistratuum circa sacra (1614), known to a small circle of Grotius' relatives and friends during his own lifetime, were rediscovered and printed in the late twentieth century. The modern edition of Grotius' correspondence, the Briefwisseling (1928-2001), includes many new finds as well. Indeed, 'lost' letters of Grotius continue to be discovered until this day. Approximately 10,000 folios of Grotius' working papers are extant in public collections in, primarily, The Netherlands, Sweden and France. ${ }^{1}$

* The research for this was made possible by fellowships at the Netherlands Institute for Advanced Study (Feb.-June 2005), at Huygens ING in The Hague, a subsidiary of the Royal Dutch Academy of Sciences (Sept. 2009-June 2010), and at Harvard University (Feb.-June 2009 and Aug. 2011-June 2012). In analyzing the fate of Grotius' book and manuscript collection, I have profited greatly from Henk Nellen's comprehensive knowledge of his extant correspondence. The Briefwisseling van Hugo Grotius, completed by Nellen in 2001, is an indispensable tool of modern-day research on the life and work of the Delft jurist, particularly his place in the Republic of Letters in the first half of the seventeenth century.

1 Briefwisseling van Hugo Grotius, ed. P.C. Molhuysen, B.L. Meulenbroek, P.P. Witkam, H.J.M. Nellen and C.M. Ridderikhoff, 17 vols. (The Hague, 1928-2001) no. 6148 (Grotius to W. de Groot, 27 March 1643), also available electronically at <http://grotius.huygens.knaw.nl/ 
Less attention has been paid, however, to the destruction or disappearance of materials once part of Grotius' personal library and archive. It is not a positive or uplifting story, of course. Nor are there reliable quantitative estimates of the losses involved. For that would assume that we have a detailed knowledge of the contents of Grotius' personal library and archive at the time of his death or even before then, which we do not. This essay analyzes the 'loss' of printed and manuscript materials during Grotius' own lifetime, particularly the confiscation proceedings initiated by the States General (i.e. the federal government of the Dutch Republic) in May 1619, following Grotius' conviction for high treason.

\section{Introduction}

There were many reasons for the disappearance or destruction of materials once in Grotius' library and personal archive. The development of a (rudimentary) postal system in the seventeenth century made it possible for scholars to circulate manuscripts and printed books in the Republic of Letters more widely than ever before. Yet peer-to-peer lending was not without risk. Things could and did get lost in the post. Not all of Grotius' correspondents were sufficiently conscientious to return materials to him on time, or, indeed, at all. He returned the compliment, of course. While he spent most of his working life as an exile in Paris, he relied on family and friends in Holland to offer him a helping hand in an ambitious programme of scholarly publication. His correspondence shows that his father, wife, younger brother and, later on, his own children were all involved in the editorial process - reading and critiquing manuscripts in Latin and Dutch, preparing printers' copies, and seeing manuscripts through the press. Following Grotius' appointment as Swedish ambassador to the French court in January 1635, friends and relatives in Holland assumed even

years>; Jacob ter Meulen and P.J.J. Diermanse, Bibliographie des écrits imprimés de Hugo Grotius (The Hague: Martinus Nijhoff, 1950); Hugo Grotius, De Republica Emendanda ed. Arthur Eyffinger et al. Grotiana (n.s.) 5 (1984); Hugo Grotius, Meletius, sive De iis quae inter Christianos conveniunt Epistola: Critical Edition with Transtlations, Commentary and Introduction ed. G.H.M. Posthumus Meyjes (Leiden: Brill, 1988); G.H.M. Posthumus Meyjes, 'Some Remarks on Grotius' Excerpta Theologica, Especially Concerning His Meletius' in H.J.M Nellen and Edwin Rabbie (eds.), Hugo Grotius, Theologian: Essays in Honour of G.H.M. Posthumus Meyjes (Leiden: Brill, 1994), pp. 1-17; Harm-Jan van Dam, 'Grotius' manuscript of De Imperio Summarum Potestatum circa Sacra identified, Grotiana 11 (1990), pp. 34-42; Hugo Grotius, Tractatus de Iure Magistratuum Circa Ecclesiastica, ed. Harm-Jan van Dam and H.J.M. Nellen, Grotiana 20/21 (1999/200o), pp. 28-33; Catalogue de Manuscrits Autographes de Hugo Grotius, 2nd ed., with annotations by W.J.M van Eysinga and L.J. Noordhoff (The Hague: Nijhoff, 1952). 
greater responsibility for the publication of his work. Blaeu in Amsterdam had become one of Grotius' favorite publishers, in fact. All of this required frequent shipments of materials between Holland and Paris, and a lot of organization and planning on the part of Grotius and his younger brother, Willem de Groot, whom he appointed "guardian of my books" in December 1639. It also increased the risk of texts going astray during Grotius' own lifetime. ${ }^{2}$

Another factor that determines the survival rate of Grotius' material legacy is, of course, how well it was taken care of after his death. Here I can only summarize a rather complicated story of transmission and dispersal that covers three-and-a-half centuries. Suffice it to say that Grotius was lucky in his heirs and descendants. His wife, Maria van Reigersberch (1589-1653), inherited all of his worldly possessions upon his death in August 1645. Three years later, she sold his entire book collection to Queen Christina of Sweden. In scholarly families, it was not uncommon for a widow to sell the tools of the trade in order to increase her own pension. Twentieth-century researchers have traced approximately fifty books purchased by Queen Christina to various libraries in Europe, including the Vatican Library, Munich University Library, Leiden University Library, the Royal Library in Stockholm, and Lund University Library. Yet Grotius' widow had no intention of parting with any of his unpublished manuscripts, Historia Gotthorum (a history of Sweden) excepted, which she also sold to Christina of Sweden, but on the condition that it would be published. Indeed, the reason why Maria van Reigersberch refused to part with any of the other manuscripts of her late husband was to find suitable editors and publishers for them. Historia Gotthorum appeared in print a year after Maria's death, courtesy of Isaac Vossius (1618-1689), a former secretary of Grotius. In 1657, Grotius' two eldest sons published his Annales et Historiae, a chronicle of the Dutch Revolt, of which the author had completed a first full draft back in $1613 .{ }^{3}$ The pace of publication notably slackened thereafter.

2 Briefwisseling, no. 4431 (Grotius to Willem de Groot, 17 Dec. 1639), Martine Julia van Ittersum, 'Knowledge Production in the Dutch Republic: The Household Academy of Hugo Grotius (1583-1645)',Journal of the History of Ideas, 72.4 (2011), pp. 523-548; C.S.M. Rademaker, 'Books and Grotius at Loevestein', Quaerendo, 2.1 (1972), pp. 2-29; Henk Nellen, Hugo Grotius: A Lifelong Struggle for Peace in Church and State, 1583-1645, trans. J.C. Grayson (Leiden: Brill, 2015), pp. 298-302, 587-591, 593-598,608-629 and Hugo de Groot: Een Leven in Strijd om Vrede, 1583-1645 (Amsterdam: Balans, 2007), pp. 236, 255-256, 475-478, 491-506.

3 Hugo Grotius, Philosophorum sententiae de fato (Paris, 1648), ff. * $2{ }^{-}{ }^{*} 3 v$; Nellen, Hugo Grotius pp. 746-748, Hugo de Groot pp. 6oo-601 and 'Reigersberch, Maria van', in Digitaal Vrouwenlexicon van Nederland. URL: <http//resources.huygens.knaw.nl/vrouwenlexicon/ lemmata/data/Reigersberch> [13/01/2014]; F.F. Blok, Isaac Vossius and His Circle: His Life until His Farewell to Queen Christina of Sweden, 1618-1655 (Groningen: Egbert Forsten, 2000), 
Grotius' second son, Pieter de Groot (1615-1678), did not get round to editing his father's Opera Omnia Theologica until the 1670s. It was a far cry from the complete works envisaged twenty years earlier. Nor did the publication contain any works of Grotius that had not appeared in print before. Following the deaths of his mother, eldest brother and uncle, Pieter de Groot had inherited the bulk of his father's manuscripts. Yet he clearly did not get round to reading let alone sorting out - what remained of his father's material legacy. The same was true of his descendants and heirs in the eighteenth century. They locked up Grotius' manuscripts in "chest no. 1," preserving them by non-use. Only as a result of a public auction in 1864 did most of Grotius' extant manuscripts cease to be family heirlooms and end up in public collections in Sweden and The Netherlands. ${ }^{4}$

The present essay focuses on one aspect of Grotius' dramatic life story and its consequences for his library and private archive: the confiscation proceedings initiated by the States General in May 1619. Grotius had been arrested in The Hague nine months earlier, while on his way to a meeting of the States of Holland (i.e. the provincial government of Holland). Years later, he still

pp. 452-458; Edwin Rabbie, 'The History and Reconstruction of Hugo Grotius' Library: A Survey of the Results of Former Studies with an Indication of New Lines of Approach' in Eugenio Canone (ed.), Bibliothecae Selectae da Cusano a Leopardi (Florence: Olschki, 1993), pp. 119-137; F.F. Blok, 'Deux letters en français de Marie de Reigersberg, veuve de Hugo Grotius', Quaerendo 20 (1990), pp. 5-23 and 87-95; Kjell Å Modéer, Hugo Grotius and Lund: The Book Collection of Hugo Grotius in the Lund University Library as an Example of the Learned and Cultural Relations Between The Netherlands and Sweden in the 17th Century (Lund, 1987); Blok, Contributions to the History of Isaac Vossius's Library, Verhandelingen der Koninklijke Nederlandse Akademie van Wetenschappen, Afdeeling Letterkunde, n.s., no. 83 (Amsterdam, 1974); E.M. Meijers, Boeken uit de bibliotheek van De Groot in de Universiteitsbibliotheek te Leiden (Amsterdam: Noord-Hollandsche Uitgevers, 1949); Folke Dovring, Une partie de l'héritage littéraire de Grotius retrouvée en Suède (Amsterdam: NoordHollandsche Uitgevers, 1949) and Nouvelles recherches sur la bibliothèque de Grotius en Suède et en Italie (Amsterdam: Noord-Hollandsche Uitgevers, 1951).

Nellen, Hugo Grotius pp. 746-748 and Hugo de Groot pp. 6oo-6o1; Hugo de Groot, Kroniek van de Nederlandse Oorlog: De Opstand 1559-1588, trans. and ed. Jan Waszink (Nijmegen: Van Tilt, 2014); Jan Waszink, 'Hugo Grotius' Annales et Historiae de Rebus Belgicis from the Evidence In His Correspondence, 1604-1644', LIAS: Sources and Documents Relating To The Early Modern History of Ideas, 31 (2004), 249-269; Martine van Ittersum, 'Confronting Grotius' Legacy in an Age of Revolution: The Cornets de Groot Family in Rotterdam, 1748-1798', English Historical Review CXXvi no. 529 (Dec. 2012), pp. 1367-1403; Catalogue ed. Eysinga and Noordhoff; L.J. Noordhoff, Beschrijving van het zich in Nederland bevindende en nog onbeschreven gedeelte der papieren afkomstig van Huig de Grootwelke in 1864 te 's-Gravenhage zijn geveild (Groningen: Noordhoff, 1953), pp. 7-19. 
deplored the confiscation, by the Stadtholder's guard, of a bag which he had carried with him, filled with papers. That, however, was the least of his troubles. As Pensionary (i.e. legal adviser) of the town of Rotterdam, he had been the right-hand man of Johan van Oldenbarnevelt, Advocate of Holland and de facto political leader of the Dutch Republic. As such, he had been closely identified with Oldenbarnevelt's policies vis-à-vis the Dutch Reformed Church. Both men were dyed-in-the-wool Erastians. In their view, the secular authorities had the final say in church government and even in church doctrine. Inevitably, this made the conflict over Arminianism inside the Dutch Reformed Church a highly charged political battle as well. When the situation threatened to spin out of control, Prince Maurice of Nassau - Stadtholder and army leader intervened and arrested Oldenbarnevelt and Grotius on charges of high treason. Both were found guilty in May 1619: while Oldenbarnevelt was executed, Grotius received a sentence of lifelong imprisonment at Loevestein Castle. Their worldly possessions were confiscated. This disastrous turn in Grotius' life resulted in a substantial loss of books and working papers. Still, the effects were decidedly mixed. Dutch friends and relatives managed to hide materials from the authorities, and, following Grotius' escape from Loevestein Castle in March 1621, in getting the confiscation decree annulled by the Court of Holland (Hof van Holland). It proved impossible, however, to retrieve all the books and manuscripts lost in the period August 1618-March 1620.5

\section{What Do We Know Already about the Confiscation of Grotius' Library and Working Papers in the Period 1618-1620?}

Grotius' conviction for high treason in May 1619 presents a major challenge for modern scholarship in determining the fate of his library and working papers. In theory, the conviction should have resulted in a straightforward confiscation of all of Grotius' worldly possessions. The reality turned out to be different. Both the States General and States of Holland claimed oversight of the confiscation proceedings and demanded a share in the loot. Moreover, the States of Holland and town of Rotterdam were entitled to documents used or produced by Grotius in his capacity as Pensionary of Rotterdam. These conflicting claims and competencies bogged down the confiscation proceedings for a long time, and also created opportunities for Grotius' friends and enemies to abscond with materials unseen. Which books and manuscripts were removed from

5 Briefwisseling, no. 2694 (Grotius to N. van Reigersberch, 31 July 1636); Nellen, Hugo Grotius pp. 165-312 and Hugo de Groot, pp. 144-262. 
Grotius' library in Rotterdam, by whom and when? Did Grotius regain access to (part of) his (confiscated) book collection while imprisoned at Loevestein Castle? What happened to his books and papers after his escape in March 1621? To further complicate matters, the Court of Holland decreed in September 1625 that any confiscated property that turned out to belong to Grotius' wife, Maria van Reigersberch, should be returned to her forthwith. In May 1630, the Court of Holland nullified the confiscation of Grotius' possessions in its entirety. What difference did these verdicts make? Was Grotius able to recover books and manuscripts in the 1630 s and 1640 os that had disappeared from sight during his imprisonment in the period 1618-1621?

A consideration of these issues has immediate ramifications for our understanding of Grotius' intellectual development, particularly the relationship between his 'early' and 'mature' works. For example, are legal historians right to assume that Grotius had access to Ms. BPL 917 (also known to us as De Jure Praedae/On the Law of Prize and Booty, written by Grotius in 1604-1608) while he was working on De Jure Belli ac Pacis (1625)? ${ }^{6}$ Although there are no straightforward answers to these questions, it is useful to investigate the parameters of the problem. I first discuss the secondary literature on the topic, then reconstruct the confiscating proceedings of $1619-1620$ and its aftermath, and finally try to assess the consequences for our understanding of Grotius' intellectual development.

The lists of the contents of Grotius' house in Rotterdam drawn up at the instigation of the States General in March 1620 have been fruitful objects of study in the twentieth century. The inventories are examined and reproduced, either in whole or in part, in the publications of G. Moll (1902), E.JJ. van der Heijden (1930), and P.C. Molhuysen (1943). As editor of the Briefwisseling, the latter was in an ideal position to compare lists of confiscated books with references found in Grotius' correspondence to his reading and writing. Molhuysen concluded that Grotius' book collection had been catalogued in a rather slipshod fashion. As far as Molhuysen could tell, the man appointed for the job Louis Elzevier, a bookseller in The Hague - had taken the books from the shelf, inspected them and then called out a shortened title or, in some cases, little more than a key term or just the name of an author. Meanwhile, Elzevier's assistant wrote down what he had heard or what he thought he had heard. Pamphlets and other materials without obvious monetary value were only

6 Peter Haggenmacher, Grotius et la doctrine de la guerre juste (Paris: PUF, 1983), p. 386, including notes 1870-1872; Benjamin Straumann, Hugo Grotius und die Antike: Römischen Recht und römische Ethik im frühneuzeitlichen Naturrecht, Studien zur Geschichte des Völkerrechts 14 (Baden-Baden: Nomos, 2007), p. 192 (footnote 433). 
described in the most general of terms - "a bunch of small and blue books of little value" (i.e. pamphlets) and "a couple of unbound books." The fact that the States General intended to sell Grotius' confiscated possessions in order to recover the costs of his trial may well explain Elzevier's failure to properly apprize pamphlets and working papers. Their financial value was close to zero at this point in time - the prisoner at Loevestein Castle was hardly the worldfamous scholar he would later become. Molhuysen also noted that certain books which one would have expected in Grotius' library, such as editions of Homer and Virgil, received no mention whatsoever in the inventories of March 1620. Questions remained in Molhuysen's mind, not just with respect to Elzevier's cataloguing methods, but also regarding the ultimate fate of Grotius' library. ${ }^{7}$

Had confiscated books been shipped to Loevestein Castle during Grotius' incarceration there? Molhuysen did not believe so. Otherwise it would be difficult to explain why the prisoner complained about a dearth of books at Loevestein Castle in his letters to Willem de Groot and his friend G.J. Vossius (1577-1649), the father of Isaac Vossius. Did Grotius succeed in reassembling his library in exile in Paris? Molhuysen again expressed his doubts. He pointed out that only a handful of the authors cited in De Jure Belli ac Pacis (1625) were represented in the inventories of March 1620. Nor did it seem likely that the verdict of the Court of Holland in May 1630 had resulted in an immediate shipment of books to Paris. Grotius was planning his return to the Dutch Republic at that point. In October 1631, he left Paris for Holland, only to flee Holland again in May 1632, when he took refuge in Hamburg. The wandering scholar did not arrive back in Paris until January 1635. Molhuysen admitted that the newly minted Swedish ambassador could have arranged for a shipment of books at that point. If so, these materials must have formed part of the book collection which Grotius' widow sold to Christina of Sweden in 1648. Yet Molhuysen doubted that sufficient proof would ever be forthcoming. Folke Dovring and E.M. Meijers took up his challenge in a series of extended essays (published in 1949 and 1951, respectively), in which they identified forty-eight books in libraries in Sweden, The Netherlands, and Italy that had once belonged to Grotius. They established that the book collection inherited by Maria van Reigersberch had indeed been shipped to Stockholm in 1648 in order to be incorporated into the library of Queen Christina. Yet

7 G. Moll, 'De confiscatie der goederen van Hugo de Groot', Oud-Holland, 20 (1902), pp. 83-111; E.J.J. van der Heijden, 'De boekerij van Grotius', Grotiana 3 (1930), pp. 18-38; P.C. Molhuysen, De bibliotheek van Hugo de Groot in 1618 (Amsterdam: Noord-Hollandsche Uitgevers, 1943), particularly pp. 1-5, 18-19; Rabbie, 'Hugo Grotius' Library', pp. 120-125. 
their investigations did not answer all the questions raised by the inventories of March 1620 - far from it. ${ }^{8}$

In 1993, the Dutch jurist Edwin Rabbie published an essay chapter on 'The History and Reconstruction of Hugo Grotius' Library: A Survey of the Results of Former Studies with an Indication of New Lines of Approach'. Not coincidentally, the author is also the modern editor of Grotius' Ordinum Hollandiae Ac Westfrisiae Pietas (1613). Any assessment of Grotius' source references is closely bound up with our knowledge of the book collection(s) to which he may have had access at any given moment in time. Rabbie concurs with Molhuysen in the latter's critique of Elzevier's shoddy cataloguing, but also warns that Molhuysen overstated his case in an effort to remedy the situation. Molhuysen's essay includes a long list of book titles and editions that allegedly match the entries in the inventories of March 1620. In Rabbie's view, it is naïve to assume that exceedingly vague entries like "three books by [Conradus] Vorstius" can ever be identified with definite book titles and editions. (Rabbie may be too pessimistic in this regard, but that by the bye.) Of course, it is not difficult for Rabbie to show that the inventories of March 1620 must be incomplete. They do not reflect Grotius' intimate knowledge of Classical poetry, for example. No mention is made of Janus Gruterus' edition of Martial (Heidelberg, 1602), which, according to Arthur Eyffinger, Grotius consulted extensively for his Instrumentum domesticum, a cycle of epigrams written in 1602-1603. Rabbie also notes the absence of any entries in the inventories of March 1620 that can plausibly be identified as referring to a presentation copy of Isaac Casaubon's De rebus sacris et ecclesiasticis exercitationes (London, 1614), discovered by Dovring in the Vatican Library in Rome. This particular work must have entered Grotius' book collection prior to August 1618. How to explain the riddle? Rabbie contends that Grotius' relatives removed books and manuscripts from his house in Rotterdam as soon as the news of his arrest reached them. Since the States General did not arrange for Grotius' book collection to be catalogued until March 1620, there was a window of opportunity of almost eighteen months. Rabbie also assumes that Willem de Groot rescued books that his elder brother had kept in his lodgings in The Hague. Unfortunately, Rabbie fails to substantiate these tantalizing suggestions. In order to arrive at firm conclusions, it is imperative to reconstruct the confiscation proceedings of 1618-1620, including the fight-back on the part of Grotius and his relatives and friends. The Briefwisseling provides key evidence in this respect. ${ }^{9}$

8 Molhuysen, De bibliotheek, pp. 1-5; Rademaker, 'Books and Grotius', pp. 7-17; footnote 6 above.

9 Hugo Grotius, Ordinum Hollandiae Ac Westfrisiae Pietas (1613): Critical Edition, trans. and ed. Edwin Rabbie, 2 vols. (Leiden: Brill, 1995), pp. 46-52; Rabbie, 'Hugo Grotius' Library', pp. 120-125; Molhuysen, De bibliotheek, pp. 18-19. 


\section{Did Grotius' Relatives Manage to Squirrel away Sensitive Materials Following His Arrest in August 1618?}

Strange to say, the States General was in no hurry to obtain the books and papers belonging to Grotius and Oldenbarnevelt following their arrest and imprisonment in August 1618. There was a reason for this. Cognizant of the fact that the States of Holland could lay claim to many papers in Oldenbarnevelt's keeping, the States General did not dare to confiscate these before the Advocate's execution in May 1619. Similar concerns seem to have applied to Grotius. Consequently, there is not a single reference to the prisoners' papers in the trial records, even though Oldenbarnevelt repeatedly asked for permission to go home to "select the registers, charters and documents belonging to the States of Holland and return these to the States of Holland", while Grotius declared that if his judges wanted to trawl through his papers, he would have no objections. ${ }^{10}$

Did the prisoner know that his family members had removed sensitive materials from his house in Rotterdam? It was his father, Jan de Groot, who played a crucial role in this regard. As he wrote to his son in August 1621, he had removed papers from Grotius' house in Rotterdam "on the day after your arrest", and taken these to his own place in Delft. Yet he had not kept them there, or at least not all of them. One set of documents had been transferred to the steward of the Earl of Hornes for safe-keeping, while another set of documents had been stored at the Liesveld estate in the Alblassserwaard, owned by Jan de Groot's employer, the Earl of Hohenlohe.11

As Pensionary of Rotterdam, Grotius had been required to attend the meetings of the States of Holland on a regular basis. To this purpose, the Rotterdam burgomaster Cornelis Claeszoon van Driel had provided him with a guestchamber in his house in The Hague. Rabbie assumes that Willem de Groot was in a position to remove materials from the guest-chamber right after his brother's arrest. That seems unlikely. Grotius' younger brother was on his grand tour, in Paris to be precise, when he learned of the dramatic events in Holland. Although he rode back to Delft in three days, frequently changing horses, the first evidence we have for his arrival at his parents' home is a letter of 15 September 1618. There was very little he could do at that point. Grotius'

10 Robert Fruin, Verhooren en andere bescheiden betreffende het rechtsgeding van Hugo de Groot (Utrecht: Kemink en Zoon, 1871), p. 73; H.J. Ph.G. Kaajan, Het archief van de familie van Oldenbarnevelt (The Hague: Rijksarchief in Zuid-Holland, 1987), p. xxii; Nellen, Hugo Grotius, pp. 264-298 and Hugo de Groot, pp. 226-255.

11 Briefwisseling, nos. 655A, 671A (Jan de Groot to Grotius, 13 June and 2 August 1621 - I owe these references to Henk Nellen). 
correspondence confirms that the books and papers he had kept in the guestchamber disappeared without a trace. In November 1635 , he complained in a letter to Willem de Groot that, following his arrest, the authorities had taken papers "of the greatest use for political affairs" from Van Driel's house in The Hague, and never given them back to him. In July 1638, Van Driel's heirs were happy to return to Willem de Groot the "wooden caskets" which had served as Grotius' filing cabinets. But they did not contain anything at that point. ${ }^{12}$

\section{To Which Books and Manuscript Did Grotius Have Access at Loevestein Castle?}

Following his conviction for high treason, Grotius was transferred to Loevestein Castle on 5 June 1619. Maria van Reigersberch joined her husband there a week later, together with their children and servants. On 8 June, Maria had petitioned the States General for permission to move some household effects from their house in Rotterdam to Loevestein Castle, along with "a few books for her husband". When permission was granted, thirty-one volumes were taken from the shelves of Grotius' library in Rotterdam and sent to Loevestein Castle. We have an itemized list of the shipment. It reveals a mixture of legal texts and the Greek and Roman classics - Aristotle, Cicero, Plato, Thucydides, Demosthenes, "a big book of Greek poetry", and a Latin-Greek dictionary, for example. For the sake of Grotius' lucrative lawyer's practice (even as a prisoner, he continued to act as jurisconsult!), at least sixteen legal texts made their way to Loevestein Castle, including Dutch and English statute books, Wielant's and Merula's treatises on Dutch legal procedures in civil cases, first published in 1558 and 1592, respectively, a treatise on "sea-laws" (perhaps Dat hooghste en oudtste Gotlantsche Waterrecht of 1603), a copy of the Corpus Iuris Civilis, Dominicus Soto's De Justitia et Jure (Venice, 1589), Alphonsus a Castro's De potestate legis poenalis libri II (second edition, Lyon, 1556), Matthaeus Wesenbecius' In Pandectas commentarii, olim Paratitla dicti, first published in 1565 , and

12 Henk Nellen, 'Hugo Grotius' Correspondence with his brother Willem de Groot', Grotiana, n.s., 24/25 (2003/04), pp. 3-24, in particular p. 5, and 'Dienstbetoon uit broederliefde. Drie onuitgegeven brieven van Willem de Groot, 1619-1621', in P.G. Hoftijzer, O.S. Lankhorst and H.J.M. Nellen (eds.), Papieren betrekkingen: zevenentwintig brieven uit de vroegmoderne tijd (Vantilt publishers, 2005), pp. 59-72, particularly p. 61; Briefwisseling, nos. 2344 (Grotius to Willem de Groot, 9 Nov. 1635), 3532 (Willem de Groot to Grotius, 19 April 1638), 3643 (Grotius to Willem de Groot, 26 June 1638), 3659, 3694 (Nicolaas van Reigersberch to Grotius, 5 and 26 July 1638 ). 
Cornelius Neostadius' De pactis antenuptialibus rerum iudicatarum observationes and his treatise on feudal law, first published in 1594 and 1602 , respectively. In addition, "two books written with the hand in folio" were sent to Loevestein Castle - perhaps Ms. BPL 917 and the manuscript of the Annales et Historiae, respectively. ${ }^{13}$

Grotius' correspondence suggests that his own books continued to reach Loevestein Castle in other ways as well. As suspected by Molhuysen and Rabbie, the inventories of March 1620 are far from complete. When Grotius wrote to his brother-in-law Nicolaes van Reigersberch (1584-1654) in June 1619, he recalled from this borrower his own copies of Optatus Afer Milevitanus' Libri sex de schismate Donatistarum (Paris, 1563) and Marcus Antonius de Dominis' De Republica Ecclesiastica (London and Frankfurt, 1617-18). In addition, Grotius requested Willem's copy of the works of the Jewish philosopher Philo Judaeus (first century AD), which apparently contained Grotius' own reading notes. Of course, Grotius' reading had never been limited to the books that he owned himself. His imprisonment made no difference in this respect. At Loevestein Castle, Grotius relied heavily on the material support of G.J. Vossius and the Leiden orientalist Thomas Erpenius (1584-1624) for his philological labors. They lent him the books which he needed to prepare his Stobaeus edition (1623), Excerpta ex tragoediis et comoediis Graecis (1626) and his Latin translation of Euripides' Phoenissae (1630). Erpenius' plans (never brought to fruition) to compile a polyglot edition of the New Testament induced Grotius to embark on his Annotationes project while still in prison, for which purpose he borrowed Hebraica from Erpenius and theological works from Vossius. In October 1620, he could inform the latter that he had completed his commentaries on the first three Evangelists. ${ }^{14}$

The constant flow of books in and out of Loevestein Castle famously became the means of Grotius' escape. On Monday morning, 22 March 1621, the prisoner stepped into the trunk that was normally used for transporting books, wearing little more than his linen underwear and silk stockings. Unwitting soldiers carried the trunk and its contents to the house of the Daetselaer family in Gorinchem, whose members served as intermediaries in the exchange of books with Vossius and Erpenius. Once the soldiers were gone, Grotius stepped

13 Nellen, Hugo Grotius, pp. 293-294 and Hugo de Groot, pp. 251-252; Heijden, 'De boekerij', pp. 18, 34-35; Moll, 'De confiscatie', pp. 84-85, 106-107; H. Vollenhoven, Broeders gevangenisse: dagboek van Willem de Groot, betreffende het verblijf van zijnen broeder Hugo op Loevestein (The Hague, 1842), pp. 182, 184-85; Rabbie, 'Hugo Grotius' Library', pp. 128-129; Molhuysen, De bibliotheek, pp. 17-19; Rademaker, 'Books and Grotius', pp. 5-6.

Rademaker, 'Books and Grotius', pp. 5-17; Molhuysen, De bibliotheek, p. 17. 
out of the trunk, donned a bricklayer's outfit (provided by the Daetselaer family) and, thus disguised, managed to flee across the rivers to Antwerp. He then continued on to Paris, where he would remain for the next ten years of his life. What happened meanwhile to his books and papers in Holland? Were his relatives able to retrieve them and ship them south? ${ }^{15}$

\section{Jan de Groot Recovers Some of His Son's Books and Papers in Summer 1621}

Maria van Reigersberch and the children traveled to France in September 1621. Willem de Groot kept his brother company in Paris over the summer. Meanwhile, their father tried to sort out Grotius' books and papers. On 19 July, he sent G.J. Vossius a message to request the latter's presence in Delft the following day. He wished to return to Vossius the books borrowed by Grotius during his imprisonment, and "discuss other things as well". Vossius used the occasion to drop off seventeen documents concerning the disputes between the Remonstrants and Counter-Remonstrants. Jan de Groot gave a short description of each document in his letter to Willem de Groot of early August 1621. The itemized list can be correlated with Grotius' extant papers in the Bibliothèque Nationale de France, Amsterdam University Library and Rotterdam Municipal Library. In all likelihood, Vossius had been asked to provide copies of state papers with an eye to Grotius' Verantwoordingh van de wettelijcke regieringh van Holland ende West-Vrieslandt [Defense of the lawful government of Holland and West-Frisia] (1622). In this pamphlet, Grotius sought to rehabilitate Oldenbarnevelt and his political and religious policies, while subjecting both Prince Maurice and the judges who had tried Oldenbarnevelt and himself to blistering attacks. As Henk Nellen notes, the exile requested documentation for his 'apology' in his letters to Nicolaes van Reigersberch of May 1621. Jan de Groot was collecting materials pertinent to the Verantwoordingh as well. He wrote to Grotius in early August that he had gathered "your petitions and other documents with respect to Oldenbarnevelt". All these materials were passed on to Grotius' wife, on the understanding that she would send them to Paris. ${ }^{16}$

15 Nellen, Hugo Grotius, pp. 302-312, 355-379 and Hugo de Groot, pp. 257-262, 298-316.

16 Bibliothèque nationale de France, Ms. Fonds latin $9722 \mathrm{ff}$. 65-72 (I owe this reference to Henk Nellen); Amsterdam University Library, Collectie Remonstrantse Kerk, III C5 f. 139, 211-224; Rotterdam Municipal Library, Collectie Remonstrantse Kerk, Ms. 38 and Ms. 566; Briefwisseling, nos. 633 (Grotius to G.J. Vossius, 23 April 1621), 642, 645 (Grotius to Nicolaes 
That summer, Jan de Groot also sought to retrieve the papers that he had spirited away from Grotius' house in Rotterdam following his son's arrest. It was not a straightforward process. As noted earlier, Jan de Groot had stored some papers at the Liesveld estate in the Alblasserwaard and given others for safekeeping to the steward of the Earl of Hornes. He wrote to Grotius in early August 1621 that he had returned to Maria all the documents "which I had taken from your library in Rotterdam", with the exception of "papers kept by the Earl of Hornes". His gentlemen's agreement with the Earl of Hornes did not allow him to touch this particular set of materials just yet:

The reason is that, as you recall, I indicated to you immediately after your sentence that I had agreed with [Hornes'] steward that I would undertake to safely transfer those papers to him or burn them. You agreed with me on that. And so I pretended to have burnt them. The next day your wife told me that you had changed your mind and wanted to keep them. It was not expedient for me to dispute with her. For if I had immediately delivered those papers to her, and if she had disclosed their existence to her brother [Nicolaes van Reigersberch] or to somebody else, and this had become public, I could have been accused of mendacity by the noble man. And so I told your wife that I had given her all the papers which I had received from Liesveld - for they had been preserved at that place, with the exception of these - and that if there still was something at another place, your brother Willem would perhaps know this and I could discuss this with him after his return from Paris. Meanwhile, you may rest assured that those papers are well and safely preserved. ${ }^{17}$

This is a crucial passage in Jan de Groot's letter. Although Grotius was a free man again, the same could not be said of his papers. If their existence became public knowledge, they were still liable to be confiscated by the authorities. What role, if any, did Willem de Groot play in salvaging his brother's papers? The letter is ambiguous on this point. Grotius' father faced a difficult balancing act: while answering Maria's queries about the whereabouts of her husband's papers, he had to keep his gentlemen's agreement with the Earl of Hornes.

van Reigersberch, 14 and 18 May 1621) and 671A (Jan de Groot to Grotius and Willem de Groot, 2 August 1621); Nellen, Hugo Grotius, p. 340 and Hugo de Groot, p. 286; Rademaker, 'Books and Grotius', pp. 16-17, 24-25; Noordhoff, Beschrijving pp. 44-45, 50, 53; Henk Nellen, 'Être à la page de l'ère de l'information: Grotius collectionneur de manuscrits sur l'union des églises', XVIIe Siècle, 67 (2015), pp. 91-117, particularly 108. 
Jan de Groot truthfully told his daughter-in-law that he had returned to her all the materials stored at the Liesveld estate, but pretended that he had to consult with Willem de Groot (conveniently in Paris) about other sets of papers hidden elsewhere. It is doubtful, however, that Willem de Groot was aware of the gentlemen's agreement between his father and the Earl of Hornes. Significantly, Jan de Groot wrote two letters on 2 August 1621, one addressed to Grotius, the other to Willem de Groot. His efforts to retrieve Grotius' papers receive no mention whatsoever in the letter to his younger son. Jan de Groot, then, was the sole person responsible for removing sensitive materials from Grotius' house in Rotterdam in August 1618, for hiding these at various locations in Holland in August 1618 and May 1619, and for retrieving some of them in July 1621. Unfortunately, his letters do not contain an itemized list of the papers handed to Grotius' wife the previous day, with the exception of the materials provided by Vossius. Nor did Maria have any intention of taking all of this material to Paris. To Jan de Groot's disappointment, she burnt "many [documents] which she considered useless". We will never know what was lost on that occasion. As for the papers left in the safekeeping of the steward of the Earl of Hornes, it is unclear whether Jan de Groot managed to recover them at a later point. Nor do we have any information about their contents. ${ }^{18}$

\section{What Happened to Grotius' Confiscated Papers?}

Although Grotius did not share Oldenbarnevelt's fate in May 1619, many of his papers were subjected to the same careless handling as Oldenbarnevelt's archive. Convicted for crimen laesae maiestatis, the Advocate of Holland was executed on 13 May 1619. Two days later, the States General proceeded to confiscate his archive. It immediately faced a conflict of jurisdiction with the States of Holland. Both institutions realized that many state papers in Oldenbarnevelt's possession properly belonged to the County of Holland. On 18 May, the States of Holland demanded that an inventory of the archive be drawn up in the presence of representatives of both institutions, "leaving to the States General what belongs to the States General, and to Holland what belongs to Holland". The papers were in such a state of disarray, however, that an initial inspection suggested it could take months to sort them out. It would be late autumn before seven trunks, filled with the Advocate's papers, could be transported from his house in The Hague to the offices of the Delegated States of South Holland, a standing committee of the States of Holland. Meanwhile, a 
visitation committee appointed by the States of Holland refused to cooperate with representatives of the States General. At the beginning of July, François van Aerssen van Sommelsdijk (1572-1641), Andries de Witt (1573-1637), Johan van Wassenaer van Duvenvoorde (1577-1645) and Albrecht Franszoon Bruynincx let it be known that they preferred to sort out Oldenbarnevelt's papers themselves. Shortly afterwards, the representatives of the States General were denied all access to the papers. Prince Maurice sought to mediate in this affair, but apparently without much success. ${ }^{19}$

The delays and confusion caused by the conflict of jurisdiction between the States General and States of Holland proved disastrous for the integrity of Oldenbarnevelt's archive. On 30 October 1619, the States of Holland noted that a few trunks filled with papers had disappeared from the Advocate's house in The Hague. In all likelihood, the visitation committee was the guilty party. Van Aerssen, a bitter enemy of Oldenbarnevelt, used the opportunity to eradicate all traces of his correspondence with the Advocate of Holland. The Delegated States of North Holland - another standing committee of the States of Holland explicitly instructed Bruynincx to select from Oldenbarnevelt's archive any document that could be of importance to them. It should also be noted that Oldenbarnevelt's kith and kin received permission from the States of Holland to remove personal and family papers on at least two occasions. Reinoud van Brederode (1567-1633), Oldenbarnevelt's son-in-law, recovered his papers in December 1619. Another son-in-law, Cornelis van der Myle (1579-1642), was given access to the five remaining trunks in the offices of the Delegated States of South Holland in November 1625 . He removed all the papers pertaining to the possessions of Maria van Utrecht (1551-1629), Oldenbarnevelt's widow. Two more trunks disappeared after his visit: one containing the correspondence of Joachim Ortell, the agent of the United Provinces in England from 1584 until his death in 1590, and another comprising "the histories and books written by Pieter Cornelis Bockenberch" (1548-1617), who had been appointed historiographer of Holland in 1591. When, in February 1631, the States of Holland belatedly woke up to the fact that they were losing oversight of their own archive, they commissioned Anthonis van der Wolf, secretary of the

19 Kaajan, Het archief van de familie van Oldenbarnevelt, pp. xxii-xxiv and Het archief van Johan van Oldenbarnevelt, 1586-16r9 (voorlopige inventaris) (The Hague: Rijksarchief in Zuid-Holland, 1984), vol. I, pp. lxxiv-lxxvi; Moll, 'De confiscatie', pp. 85-87. Although the Advocate of Holland was required to transfer relevant materials to the archive of the States of Holland, Oldenbarnevelt had only done so intermittently. He had been the Keeper of Holland's Charters (chartermeester) since 1604. In that capacity, he must also have kept state papers at his home. 
Holland Chamber of Accounts (Rekenkamer), to draw up an inventory. At that point, the remainder of Oldenbarnevelt's papers consisted of two of the original seven trunks. Of course, it did nothing to stop the disintegration of Oldenbarnevelt's archive. When Herbert van Beaumont, keeper of the county's charters, did his own inspection in 1665 , he concluded that many of the most important papers were missing. In the nineteenth and twentieth centuries, the Kingdom of the Netherlands retrieved parts of Oldenbarnevelt's archive from various sources, including the descendants of members of the visitation committee. This is a long story, however. Suffice to say that the States of Holland subjected Grotius' confiscated books and papers to similarly chaotic archiving procedures. Partly incorporated into Oldenbarnevelt's archive, they shared its fate. ${ }^{20}$

On 15 May 1619, the States General appointed Johan Hallingh as the trustee for the confiscated possessions of Oldenbarnevelt and Grotius. Yet the conflict of jurisdiction between the States General and States of Holland prevented him from making any headway that summer. Two Rotterdam schepenen (aldermen), who acted independently from Hallingh, made an inventory of the furniture in Grotius' house in Rotterdam sometime before 8 June. Nor did Hallingh draw up the itemized list of thirty-one volumes taken from Grotius' library and shipped to Loevestein Castle that same month. On 28 June, the States of Holland arrogated to themselves all of Grotius' immovable possessions found within the county's perimeters, so as to maintain "the right of confiscation inherent in a sovereign lordship and the high jurisdiction of a feudal lord". Five days later, the Holland Chamber of Accounts warned Hallingh not to touch any of the prisoner's possessions in Holland. Needless to say, this made it impossible for him to do his work. At the request of the States General, Prince Maurice intervened in the matter in the middle of July. Hallingh was confirmed in his position as sole trustee of the prisoner's possessions in Holland. On 12 August, he received permission from the States General to sell the prisoner's confiscated possessions, a decision endorsed by the States of Holland eight days later. Both institutions had reckoned without Maria van Reigersberch, however. ${ }^{21}$

20 Kaajan, Het archief van de familie van Oldenbarnevelt, pp. xxii-xxvii and Het archief van Johan van Oldenbarnevelt, vol. I, pp. lxxv-lxxx; Briefwisseling, no. 2345 (Grotius to Willem de Groot, 10 Nov. 1635).

21 Heijden, 'De boekerij', pp. 18-19, 34-35; Moll, 'De confiscatie', pp. 84-91, 107-112; Vollenhoven, Broeders gevangenisse, pp. 220-227; Caspar Brandt and Adriaan van Cattenburgh, Historie van het Leven des Heeren Huig de Groot, 2 vols. (Dordrecht and Amsterdam, 1727), vol. I, p. 219. 
Grotius' wife petitioned the Court of Holland (Hof van Holland) on 24 August to confirm her husband in the enjoyment of a privilege granted to the Delft citizenry by Duke Albrecht of Bayern: regardless of the offense committed, a burgher of Delft had the opportunity to recover his confiscated possessions for the payment of sixty guilders. When the Court of Holland decided against her in early November, she immediately lodged a number of appeals, both with the Court of Holland and the States General. Although she would eventually be successful, this was far from clear in the autumn of $1619 .{ }^{22}$

Meanwhile, the Delegated States of South Holland had taken matters into its own hand. Two of its members - Johan Claaszoon Dierhout (d. 1626) and Van Wassenaer-Duvenvoorde, who was responsible for sorting out Oldenbarnevelt's papers as well - received instructions to travel to Rotterdam together with Hallingh, and retrieve "documents, books and papers" from Grotius' house there. Any materials directly relevant to Rotterdam could be handed to the town magistrates, everything else had to be taken to The Hague. Van WassenaerDuvenvoorde, Dierhout and Hallingh entered Grotius' house on 3 October 1619. Brushing aside the protests of Grotius' wife, they removed part of her husband's papers, without, however, compiling any kind of inventory. Grotius wrote to Willem de Groot in November 1635 that "many of these papers pertained to Dutch history and law". In addition, materials "of the greatest use for political affairs" had been removed from his guest-chamber in Van Driel's house in The Hague, probably also in October 1619. His wife recalled that these documents - "much more exquisite" than the ones appropriated by Van Wassenaar-Duvenvoorde - had been taken to "the house of Johan Basius" (1575-1646), Auditor General of Holland. This should not surprise us: it was at the prompting of the Holland Chamber of Accounts that the States of Holland had interfered in the confiscation proceedings in summer 1619. It is another indication that Grotius' confiscated papers received the same shoddy treatment as Oldenbarnevelt's archive. ${ }^{23}$

Following the verdict of the Court of Holland of May 1630, both Willem de Groot and Nicolaes van Reigersbergh made great efforts to locate Grotius' confiscated papers. The exile egged them on, of course. In one letter after another, he expressed his ardent desire to have his books and papers back, so he could complete the Annales et Historia, for example. In his view, their whereabouts had to be known to several Dutch politicians, including Jacob

\footnotetext{
22 Idem; Briefwisseling, no. 1506 (Grotius to N. van Reigersberch, 24 May 1630).

23 Brandt and Cattenburgh, Historie, Vol. I, pp. 219-120; Briefwisseling, nos. 2344, 2345, 2431 (Grotius to Willem de Groot, 9 and 10 Nov. 1635 and 10 Jan. 1636); Moll, 'De confiscatie', pp. 85, 90-91.
} 
Cats (1577-1660), Pensionary of Holland, and the usual suspects Van Aerssen, Van der Wolf, Basius and Van Wassenaer-Duvenvoorde. As noted earlier, Van Aerssen and Van Wassenaer-Duvenvoorde had been members of the visitation committee appointed by the States of Holland that had shamelessly pillaged Oldenbarnevelt's archive. Yet Willem de Groot did not dare to approach the powerful Van Aerssen, whom Grotius regarded as his mortal enemy, and targeted Van Wassenaer-Duvenvoorde, Van der Wolf and Basius instead. Their response was mixed. Van Wassenaer-Duvenvoorde contended in September 1635 that he had simply done his duty and handed the papers to the (Delegated) States of (South) Holland. Nor could Van WassenaerDuvenvoorde tell Willem de Groot "what had been done with them or where they had been hidden". In response, Grotius suggested that Van der Wolf might know where to find the confiscated papers, or otherwise the members of the Delegated States of South Holland. Willem de Groot did not have any luck with Van der Wolf either. In December 1635, he reported that Van der Wolf claimed never to have seen any of Grotius' papers. Willem did not know where to turn next, as

there is nobody among the members of the States of Holland [right now] who governed the commonwealth back then [i.e. in October 1619], apart from Van Wassenaer-Duvenvoorde, who is also ignorant of everything, as I wrote to you before. ${ }^{24}$

Yet Willem de Groot could offer his brother one ray of hope: "those documents relevant to politics" which had been taken to Basius' house in October 1619 had arrived back at "the house of our father" in Delft. They were shipped to Paris in late September 1635, packed in three trunks. Sadly, Willem failed to describe the documents individually. We are better informed about another trunk of papers obtained from Basius in November 1637 and shipped to Paris seven months later. It contained six bound volumes of resolutions of the States of Holland, covering the years 1577-16oo, which, Grotius recalled, he had put together during his tenure as Pensionary of Rotterdam. The Rotterdam Municipal Archives acquired these volumes in the nineteenth century. Otherwise, the

24 Briefwisseling, nos. 1166 (Grotius to Willem de Groot, 22 August 1627), 1977 (Grotius to N. van Reigersberch, 15 Feb. 1635), 2197, 2250, 2344, 2345, 2431, 2485 (Grotius to Willem de Groot, 27 July, 23 Aug., 9 and 10 Nov. 1635 and 10 Jan. and 21 Feb. 1636), 2200 and 2434 (Grotius to N. van Reigersberch, 27 July 1635 and 10 Jan. 1636), 2295 and 2388 (Willem de Groot to Grotius, 29 Sept. and 12 Dec.1635); 3659, 3694 (Nicolaas van Reigersberch to Grotius, 5 and 26 July 1638). 
papers confiscated in October 1619 were never returned, neither to Grotius nor to his family and descendants. ${ }^{25}$

We may deduce what happened from the recent discovery of Grotius' unpublished treatise Tractatus de iure magistratuum circa sacra (1614). In May 1997, Nellen found two copies of the Tractatus - a draft in the hand of Willem de Groot and a fair copy in the hand of G.J. Vossius - among Oldenbarnevelt's papers in the South Holland Public Records Office in The Hague. In all probability, these copies were never intended for the Advocate of Holland. A mix-up must have occurred when the confiscated papers of Grotius and Oldenbarnevelt were incorporated into the archive of the States of Holland. It is entirely possible that the man entrusted with this task, Van der Wolf, literally had no idea which was which. The extant inventory of $163^{1}$ testifies to his sloppiness. The Tractatus is not listed separately, but subsumed under entry LVI: "A large bundle of documents concerning the ecclesiastical troubles and disputes". No wonder, then, that neither Van der Wolf nor other members of the (Delegated) States of Holland were able to help Willem de Groot in his search for his brother's confiscated papers. Moreover, materials may have disappeared long before Van der Wolf drew up his inventory. Who could stop members of the visitation committee from pillaging Grotius' confiscated papers as well as Oldenbarnevelt's archive, especially if documents were deposited pell-mell in the offices of the Delegated States of South Holland? ${ }^{26}$

\section{What Happened to Grotius' Confiscated Books?}

Determined to salvage her husband's valuable book collection, Maria van Reigersberch unexpectedly received the help of Rotterdam magistrates in October 1619. Ordered to vacate the Pensionary's residence, she immediately

25 Briefwisseling, no. 2197 (Grotius to Willem de Groot, 27 July 1635), nos. 2295, 2388 (Willem de Groot to Grotius, 29 Sept. and 12 Dec. 1635), nos. 2608, 2691 (Grotius to Willem de Groot, 30 May and 31 July 1636), no. 2613, 2694, 2705, 2822, 2904 (Grotius to N. van Reigersberch, 30 May, 31 July, 8 Aug., 30 Oct., and 18 Dec. 1636), 2925, 2958, 3023, 3323 (Grotius to N. van Reigersberch, 15 Jan, 12 Feb., 10 April, and $3_{1}$ Oct. 1637), 3327 (Willem de Groot to Grotius, 2 Nov. 1637), 3643 (Grotius to Willem de Groot, 26 June 1638) 3638, 3712, 3886 (Grotius to N. van Reigersberch, 7 Aug., 21 Nov. and 11 Dec. 1638), 3694 (N. van Reigersberch to Grotius, 26 July 1638); Noordhoff, Beschrijving, pp. 12-13.

26 Harm-Jan van Dam, 'Le droit et le sacré selon Grotius', Grotiana 20/21 (1999/200o), pp. 12-27; Grotius, Tractatus; Hugo Grotius, De Imperio Summarum Potestatum Circa Sacra, ed. and trans. by Harm-Jan van Dam (Leiden: Brill, 2001), pp. 45-48, particularly footnote 2, p. 47 . 
asked the States General for permission to ship the confiscated furniture, books and papers to Loevestein Castle. In response, the States General instructed Hallingh to return to Rotterdam to apprize the confiscated possessions, prior to their removal elsewhere. In late March 1620, a list of contents was drawn up in the presence of Hallingh, a notary and two Rotterdam aldermen. Like many inventories of the period, it only provides brief descriptions of the furniture, cutlery, and bedclothes found in the Pensionary's residence. Their total value amounted to less than 800 guilders. It is disappointing, however, that the expert engaged by Hallingh to apprize Grotius' book collection Louis Elzevier - made a complete hash of it. As Molhuysen and Rabbie point out, titles which one would have expected in Grotius' collection are not listed in the inventory, including several books known to have been in Grotius' possession prior to August 1618. The inventory, then, should be handled with great care and circumspection. ${ }^{27}$

It is far from clear what happened to Grotius' confiscated books following Elzevier's appraisal. Were all of them removed to Loevestein Castle in April 1620? It seems unlikely: Grotius continued to borrow materials from Erpenius, G.J. Vossius and Willem de Groot, for example. Nor did he regain access to his book collection after his escape from Loevestein Castle in March 1621. It had always been the intention of the States General to sell the assets of Oldenbarnevelt and Grotius in order to pay for their trials. The total value of Grotius' confiscated book collection was estimated at 340 Dutch guilders, not an insubstantial sum of money. (Presumably, it would also have been easier to auction off Grotius' valuable books than his modest furniture.) In March 1621, the States of Holland discussed the slow pace of the confiscation proceedings with the Advocate-Fiscal (i.e. public prosecutor) of Holland, who promised to do better. A few possessions of Maria van Reigersberch were seized three days after her husband's flight to Antwerp, for example. In August and October 1623 and again in January 1624, the States General asked the States of Utrecht and States of Holland to submit final accounts for the confiscated assets in their territories - Johan Doublet (1580-1650), Receiver General of the Dutch Republic, was still owed 72,00o guilders for the costs of the trials. Still, it is highly improbable that any confiscated books were sold in the meantime. Maria van Reigersberch had petitioned the Court of Holland in August 1619, asking the judges to confirm that, as a Delft citizen, her husband was entitled

27 Heijden, 'De boekerij', pp. 19-21, 23-36; Moll, 'De confiscatie', pp. 89-92, 101-107; Vollenhoven, Broeders gevangenisse, pp. 236-242; Rabbie, 'Hugo Grotius', pp. 120-122, 124-125; Molhuysen, De bibliotheek, pp. 1-4, 6-19; Brandt and Cattenburgh, Historie, vol. I, pp. 221-222. 
to redeem his confiscated possessions for the payment of sixty guilders. Although the wheels of justice turned slowly, it did have one big advantage: a sale of confiscated possessions was out of the question for the duration of the court proceedings. ${ }^{28}$

The protracted legal wrangling does raise the question whether Grotius had access to Ms. BPL 917 (i.e. the manuscript of De Jure Praedae) while writing De Jure Belli ac Pacis. Many modern-day scholars assume that he did. Did Maria van Reigersberch take it to Paris together with other manuscript materials Grotius had worked with at Loevestein Castle? But why should the States General and Prince Maurice be inclined to be lenient in this matter? In their view, Grotius was still a fugitive from justice. Perhaps Ms. BPL 917 was among the papers that Jan de Groot removed from his son's house in Rotterdam in August 1618 and returned to Grotius' wife three years later. If this was not the case, however, then the earliest opportunity at which Grotius could have regained access to the manuscript was after the publication of De Jure Belli ac Pacis. In September 1625, the Court of Holland responded favorably to a petition submitted by Maria van Reigersberch the previous summer. The Court restored her in the possession of half the confiscated assets once jointly owned by her and her husband. Unfortunately, Grotius' extant correspondence does not reveal whether any confiscated books or papers were returned to his wife at that point. Only in May 1630 did the Court of Holland annul the confiscation of all of Grotius' possessions. Still, there is no evidence of any immediate shipments to Paris. Grotius' correspondence suggests that he only gave serious thought to reassembling his personal archive and book collection after his appointment as Swedish ambassador. Whether, and when, Grotius had access to Ms. BPL 917 as an exile in Paris will have to be deduced from a systematic comparison of the quotations and marginal source references in Ms. BPL 917 and the 1625 and 1630 editions of De Jure Belli ac Pacis. Such a comparison has yet to be undertaken. ${ }^{29}$

28 Moll, 'De confiscatie', pp. 87-89, 93-97; Vollenhoven, Broeders gevangenisse, pp. 248, 114117, 141-143, 148; Molhuysen, De bibliotheek, pp. 4-5.

29 Moll, 'De confiscatie', pp. 98-100, 107-112; Brandt and Cattenburgh, Historie, vol. I, pp. 320-321; Molhuysen, De bibliotheek, pp. 4-5; Briefwisseling, no. 1166 (Grotius to Willem de Groot, 22 Aug. 1627), 1155 and 1169 (Maria van Reigersberch to Hugo Grotius, 27 June and 4 Sept. 1627), 1176, 1200, 1279, 1300, 1336, 1349 (Grotius to Nicolaes van Reigersberch, 30 Sept. \& 27 Nov. 1627, 24 June, 19 Aug., 11 Nov. and 16 Dec.1628), 1361, 1403 (Nicolaes van Reigersberch to Grotius, 6 Jan. \& 27 May 1629), 1508 (Grotius to Willem de Groot, 31 May 1630). 


\section{Conclusion}

The fate of Grotius' book and manuscript collection suggests that the 'loss rates' of printed and manuscript materials in Western Europe are closely correlated in the early modern period. Just the simple fact that manuscript materials were stored in the same location as printed texts - bound together in one volume, for example, or sitting side-by-side on a bookshelf - increased the chance that they would share a common destiny. This could be something as dramatic as destruction in war, or the more mundane threat of damage by fire or water. It is doubtful, however, that reliable statistics will become available any time soon. The manuscript catalogues of public archives and libraries in Europe and North America are of uneven quality, particularly with respect to early modern materials. Too often I have had to open boxes of archival materials with just a year listed on the outside of the box, and little else besides in the catalogue. Nor have probate inventories and scholarly correspondence from the early modern period been analyzed yet with an eye to quantifying the production and destruction of manuscripts. ${ }^{30}$ Even if we could compile datasets large enough to permit statistical analysis, the uncertainty principle of Heisenberg would still apply. The graphs and tables presented elsewhere in this volume pertain to production and loss rates in aggregate. They do not explain why a particular collection of books or manuscripts, or even just one item within a particular collection, survives until today, while others are no longer extant.

Still, the historian's craft yields a few rules of thumb. As every archival researcher knows, it is important to consider a document's physical and historical contexts. Neil Harris correctly notes that for ephemera to survive the ages, they need to 'latch on' to bigger physical objects - a quarto or folio volume, for example. Moreover, readers and other users cause printed and

30 Eltjo Buringh's Medieval Manuscript Production in the Latin West: Explorations with a Global Database, Global Economic History Series VI (Leiden: Brill, 2011) is an attempt to quantify both mediaeval manuscript production and subsequent loss rates in England and the rest of the world. Large databases containing the correspondence of members of the Republic of Letters in the seventeenth and eighteenth centuries are now available online, such as Mapping the Republic of Letters, available at <http://republicofletters .stanford.edu/>, Early Modern Letters On-Line, available at <http://emlo.bodleian.ox.ac .uk/>, and Circulation of Knowledge, available at $<$ http://ckcc.huygens.knaw.nl/>. However, these databases have so far been used for network analysis, not for quantifying the production and loss rates of manuscripts and printed books. See, for example, Yves Gingras, 'Mapping the structure of the intellectual field using citation and co-citation analysis of correspondences', History of European Ideas, 36 (2010), pp. 330-339. 
manuscript materials to deteriorate over time. The best preservative is a fair amount of neglect, though not too much of it. Grotius' working papers are a case in point. Most documents extant today were bound into large, sturdy volumes in the late 1630 s and early 1640 s, indexed by the Parisian exile himself. With a few exceptions, these volumes remained in the possession of the Cornets de Groot family for centuries, gathering dust in trunk "no. 1": in other words, preservation through non-use. For Grotius' heirs and descendants, it was a matter of filial piety and family honor to hold on to his material legacy. The Cornets de Groot family, which joined the regent elite of Rotterdam in the second quarter of the eighteenth century, had both the social status and the financial means to do so. Grotius' fame as a scholar also helped to ensure the survival of his working papers. At the time of his death in 1645 , his manuscripts were highly sought-after and commanded large sums of money. This was, of course, an important incentive for anybody in possession of his working papers to preserve them carefully. ${ }^{31}$

All this stands in stark contrast to the cavalier treatment of Grotius' book and manuscript collection by the Dutch authorities following his arrest on charges of high treason in August 1618. At that point, Grotius was hardly the prince of humanists and international star that he would become in Paris. He was lucky to escape with his life, in fact. Caught up in a political whirlwind, the collection of books and manuscripts that he had brought together in the Pensionary's residence in Rotterdam quickly disintegrated. Of course, his relatives went to great lengths to salvage what they could. However, it is unclear which documents his father managed to squirrel away and hide at various places in Holland, which materials he retrieved in July 1621 (and later), and which of these his wife decided either to ship to Paris or destroy. The confiscation proceedings initiated by the States General in May 1619 caused even more havoc, largely due to its conflict of jurisdiction with the States of Holland. Two members of the Delegated States of South Holland entered the Pensionary's residence in October 1619 and removed papers without compiling an inventory or even supplying Grotius' wife with a receipt. One part of these papers was incorporated into the archive of Johan van Oldenbarnevelt, Grotius' erstwhile political patron, and thus shared its dismal fate. Another part ended up in the

31 Neil Harris, 'The Italian Renaissance Book: Catalogues, Censuses and Survival', in Malcolm Walsby and Graeme Kemp (eds.), The Book Triumphant: Print in Transition in the Sixteenth and Seventeenth Centuries (Leiden: Brill, 2011), pp. 26-56, in particular p. 52; Van Ittersum, 'Confronting Grotius' Legacy in an Age of Revolution', pp. 1370-1373, 1375, 1398-1400; F.F. Blok, 'Deux lettres en français de Marie de Reigersberg, veuve de Hugo Grotius', Quaerendo, 20 (1990) pp. 5-23, 87-95. 
possession of Johan Basius, Auditor General of Holland, who would be the only person to give back previously confiscated papers. Unfortunately, we lack detailed descriptions of the materials returned by Basius in 1635 and 1637, except for the six bound volumes of resolutions of the States of Holland, currently in the Rotterdam Municipal Archives. (Apparently, Basius had felt no need to deposit these volumes in the archive of the States of Holland, even though he had ample opportunity to do so.)

We know even less about what happened to the printed books in the Pensionary's residence in Rotterdam, apart from the fact that Maria van Reigersberch shipped thirty-one volumes (including manuscripts) to Loevestein Castle in June 1619 and that Louis Elzevier made a muddle in appraising the remainder. While the Court of Holland effectively reversed the confiscation of Grotius' possessions in May 1630, the Parisian exile never succeeded in retrieving all of the books and manuscripts confiscated by the Dutch authorities. It is also unclear when certain materials came back into his possession. A case in point is a four-volume edition of Thomas Aquinas' Summa Theologiae (Antwerp, 1569-1570) acquired by Grotius from Dom Emmanuel of Portugal, probably at the time of writing of Ms. BPL 917 (1604-1608). Appraised by Louis Elzevier at 12 guilders in March 1620, this splendid edition of Aquinas was sold by Grotius' wife to Christina of Sweden twenty-eight years later. It is still extant at Lund University Library. ${ }^{32}$ What we do not know, however, is when exactly Grotius regained access to the four-volume set following his escape from Loevestein Castle. The same is true of quite a few other books once owned by Grotius and extant today.

This suggests that Quellenforschung - always a tricky business - is doubly so in the case of Grotius' writings. We need to give careful thought to the question when, and under which circumstances, he could have had access to a particular printed book or manuscript. His checkered life makes sweeping generalizations impossible. I suspect, however, that he is not unique in this respect, and that a similar story could be told with respect to many other scholars and statesmen in early modern Europe. True Quellenforschung is the art of the possible: in our historical analysis, we should ask the right questions of the right sources, and never loose sight of the particular.

32 Lund University Library, Bibl. Grotiana 4: Corpus Iuris Canonici, 3 volumes (Antwerp: Christopher Plantin, 1569-1570); Dovring, Une Partie de l'Héritage Littéraire de Grotius Retrouvée en Suède, p. 241; Heijden, 'De boekerij', p. 34; Martine Julia van Ittersum, 'The Working Methods of Hugo Grotius: Which Sources Did He Use and How Did He Use Them in His Early Writings on Natural Law?', in John W. Cairns and Paul J. du Plessis (eds.), Ad Fontes: Reassessing Legal Humanism and its Claims (Edinburgh: Edinburgh University Press, forthcoming). 